Original Article

\title{
EARLY SPRING NECTAR AND POLLEN AND INSECT VISITOR BEHAVIOR IN TWO CORYDALIS SPECIES (PAPAVERACEAE)
}

\author{
Bożena Denisow* \\ Monika Strzałkowska-Abramek \\ Małgorzata Bożek \\ Anna Jeżak
}

\author{
Department of Botany, Laboratory of Horticultural Plant Biology \\ University of Life Sciences in Lublin, 15 Akademicka Str., 20-950 Lublin, Poland \\ *corresponding author: bozena.denisow@up.lublin.pl \\ Received 02 July 2013; accepted 25 March 2014
}

\begin{abstract}
A bstract
This study, conducted in 2008 and 2012 - 2013, evaluated the flowering pattern (seasonal and diurnal), the abundance of flowering, nectar, and pollen yield, and insect visitor activity for Corydalis solida (L.) Clairv. and C. cava Schweig. et Koerte. The populations occur in the ground layer of a deciduous forest (Fagetalia ordo, Querco-Fagetea class) in a natural gorge within the current area of the UMCS Botanical Garden in Lublin, Poland $\left(51^{\circ} 16^{\prime} \mathrm{N}, 22^{\circ} 30^{\prime} \mathrm{E}\right)$. The phenology of Corydalis species showed distinct year-to-year plasticity (e.g., blooming period in March - April or in April - May; duration 18 - 42 days). The most intensive flower opening was noted in the early morning hours (85-90\% of daily openings occurred between 6.00 and $10.00 \mathrm{~h}, \mathrm{GMT}+2 \mathrm{~h}$ ). The average sugar yield was similar at $4.6 \mathrm{~kg} / \mathrm{ha}$ (C. cava) and $5.2 \mathrm{~kg} / \mathrm{ha}$ (C. solida), but the average pollen production differed and reached $2.1 \mathrm{~kg} / \mathrm{ha}$ ( $C$. cava) and $4.1 \mathrm{~kg} / \mathrm{ha}$ ( $C$. solida). The flower-visitor interaction in Corydalis species involved both biological (early pattern of diurnal flowering, protandry, pollen presentation at the moment of anthesis) and morphological (nectar hidden in deep spur) features. Apis mellifera foragers predominated on both Corydalis species (mean of total visitors, $68.0 \%$ to $C$. solida; $62.5 \%$ to $C$. cava) and foraged mainly for pollen ( $82 \%$ of foragers), while bumblebee queens (mean of total visitors, $32.0 \%$ to C. solida; $37.5 \%$ to $C$. cava) collected mainly nectar ( $68.0 \%$ of foragers).
\end{abstract}

Keywords: Apis mellifera, bee pasture conservation, Bombus spp., deciduous forests, floral rewards.

\section{INTRODUCTION}

Open and forest/scrub habitats are documented as familiar for bees (Apoidea) (Banaszak, 1983; 1992). In Poland, total forest area is 9.1 million ha (ca. $28.0 \%$ of acreage) (Wasiak, 2013). Habitats of deciduous forests constitute $45.5 \%$ of the total forest area and are critical in the maintenance of the food continuity supply for visiting insects and potential pollinators of commercial crops (Delaplane and Mayer, 2000; Kołtowski, 2006; Lipiński, 2010). The melliferous value has been established for several forest species in the former Soviet Union by Gluchov (1950), in Ukraine by Bodnarczuk et al. (1993), and in Poland by Szklanowska (1973; 1979). Palynological research confirms that forest vegetation makes up a large proportion in the Apoidea diet, mainly in spring (up to 40\%) (Teper, 2006; Stawiarz and Wróblewska, 2010). The flower-visitor interaction is based on various relationships, including physiological and biological interactions (Faegri and van der Pijl, 1979; Fahn, 1988; Ashman and Shoen, 1994; Goulson, 1999). Understanding these interactions is essential during the selection of plants for effective bee pastures (Delaplane and Mayer, 2000).

The species of the genus Corydalis are temperate zone geophytes that are native to northern Europe and Asia, and they prefer open moist meadows or shady forest habitats (Higashi et al., 1988; Bodnarczuk et al., 1993; Olesen, 1996; Goldenberg and Zobel, 1997; Yasaka et al., 1998; Zhang et al., 2009). In Poland, the Corydalis species develop on 
deciduous forest types of habitat characteristic for phytocoenoses from Fagetalia ordo, Querco-Fagetea class (Matuszkiewicz, 2012). The species from the genus Corydalis are also frequent on stream and river banks, at the bottom of precipices, and in parks (Rutkowski, 2004).

This paper describes one in a series of studies on the nectariferous and polleniferous potential of species across natural plant communities (e.g., Denisow, 2009a, 2011). The main issue here was to determine the relationship between blooming biology (phenology, diurnal pattern, flower morphology, floral reward) and the insect visitors for Corydalis solida and C. cava. We also estimamted the total nectar and pollen yield to evaluate if Corydalis species are suitable for enriching early spring bee pastures.

\section{MATERIAL AND METHODS}

\section{Study site}

Observations were conducted in the years 2008 and 2012 - 2013. The experimental patches, with the vegetation typical for the ground layer of deciduous forest (Querco-Fagetea class), were located in a natural gorge within a current area of the Botanical Garden of Maria Curie-Skłodowska University, in Lublin, Poland ( $51^{\circ} 16^{\prime} \mathrm{N}, 22^{\circ} 30^{\prime} \mathrm{E}, 200 \mathrm{~m}$ a.s.l.). The tree layer consisted of Acer platanoides L., Tilia cordata Mill., Fagus silvatica L., and Padus avium Mill., and in the shrub layer, Sambucus nigra L. and Corylus avellana L. occurred.

\section{Study species}

Corydalis solida (L.) Clairv., and C. cava Schweig. et Koerte belong to the family Fumariaceae (Rutkowski, 2004) or Papaveraceae according to the modern APG III system (Angiosperm Phylogeny Group, 2009). The plants are perennials with the bulb developing at a depth of $5-10 \mathrm{~cm}$. Flowers, arranged in a raceme inflorescence, are perfect, zygomorphic and consist of two sepals and two pairs of converging petals; one of the outer pair is formed into a short and rounded bag-like spur, and the inner petals are connected at the tip (Heywood, 1985; Rutkowski, 2004).

\section{Flowering and insect visitor activity}

Protocols described by Jabłoński and Szklanowska (1997) and Denisow (2009b) were applied. During the growing seasons, the onset and length of the blooming period was established. Because of the time investment required for the observations, the diurnal pattern of blooming was established only in 2008 and 2013. The observations were conducted from 6.00 until 19.00 (GMT $+2.00 \mathrm{~h}$ ), and in one-hour intervals, newly opened flowers were counted ( $n=15$ inflorescences per species). Simultaneously, the pattern and intensity of insects visits were recorded ( $n=4$ random plots, $1 \mathrm{~m}^{2}$, per species). These observations were conducted for three consecutive days, at the full bloom phase of the population. During each census of observation (3 - $6 \mathrm{~min}$ ), the total number of visiting insects was recorded and the type of forage (nectar vs. pollen) noted. To determine the flower lifespan, the buds ( $n=8-12$ per year) were randomly chosen and marked on different individual plants. The entire flower lifespan was defined as the period from bud opening until petal wilting. The number of florets per raceme ( $n=24-30$ ) and the number of inflorescences on random circular areas $0.1 \mathrm{~m}^{2}$ (36.7 $\mathrm{cm}$ in diameter) were established. The data were converted to the number of flowers per $1 \mathrm{~m}^{2}$ of the surface and used to estimate the total nectar and pollen yield.

\section{Nectar secretion}

We examined secretion using the tulle isolators and the pipette method (Jabłoński, 2002). The data from 2008 and 2013 are presented, as some isolators in 2012 were stolen, and the remaining samples seemed to be unrepresentative. Nectar collection was conducted in 3 - 5 replications during the blooming period. In each replication, 5 - 7 samples were collected; a single sample contained nectar from 11 - 20 flowers. Total sugar concentration was measured with an Abbe refractometer. Nectar volume and sugar concentration were used to calculate the total sugar mass in each sample. Relevant calculations allowed determination of the amount of sugars produced per 10 flowers (in mg) and per unit area (in kg).

\section{Pollen production}

The mass of pollen was determined in the full blooming phase. Mature but unopened anthers ( $n=200$ ) were collected in weighed glass containers in four replications. Subsequently, the glass containers with anthers were placed into a dryer (ELCON CL 65) at ca. $33^{\circ} \mathrm{C}$. The pollen was rinsed from anthers once with pure ether and with $70 \%$ ethanol. Pollen viability was tested in standard acetocarmine slides $(n=300)$. 


\section{Meteorological factors}

Weather data were obtained from a local weather station. Monthly and decade means were compared to the long-term data (1951 - 2010). The year 2008 was colder compared to the long-term data, with the exception of the initial months of the year (January, February, and March), when the air temperature was on average above $\left(0.4-1.8^{\circ} \mathrm{C}\right)$ the long-term data (mean $=-3.8^{\circ} \mathrm{C}$ ). The total precipitation in February was $70 \%$ lower than long-term data (mean $=40.2 \mathrm{~mm})$. February 2012 was relatively cold $\left(5.4^{\circ} \mathrm{C}\right.$ lower compared to the long-term mean); conversely in March and April, $1.2^{\circ} \mathrm{C}$ and $3.8^{\circ} \mathrm{C}$ above the norm was recorded, respectively. The precipitation level of the autumn-winter of 2012 - 2013 was approx. 70\% lower than in the long term. The first months of the year 2013 were colder compared to the long-term data, with an extremely high snow layer noted in April.

\section{Data analysis}

Data are presented as means with SD. The standard analysis of variance was applied (Stanisz, 1996). Post hoc comparison of means was done using the Duncan t-test. The level of statistical significance for all analyses was set at $\alpha=0.05$. All analyses were performed using Statistica ver. 6.0 (StatSoft Poland, Krakow).

\section{RESULTS}

Corydalis species were among the earliest blooming species in the studied patches and co-flowered with Galanthus nivalis L. and Hepatica nobilis Mill. The termination of Corydalis species blooming overlapped with the full blooming of Anemone nemorosa L. and with the initial phase of blooming for Pulmonaria obscura L. Under the climatic conditions of eastern Poland, during the study seasons, the blooming of Corydalis species occurred in March-April or in AprilMay (Tab. 1). The length of the flowering period differed between species and between growing seasons. In each study year, C. solida started to bloom first (approx. a week earlier than $C$. cava). The length of the flowering period ranged from 19 to 42 days for $C$. solida (mean $=30.0 \pm 11.5$ ) and was one week longer than the flowering length of C. cava (range 18 - 37 days; mean $=28.3 \pm 9.6$ ). The seasonal rhythm of flowering in 2008 differed significantly from that in 2013 (Fig. 1). In the first two weeks of 2008, the flower development rate was slow (up to $5 \%$ per day), and the peak of flowering for the population was observed in the third week, in contrast to 2013 when the flowering peak had already occurred on the fifth day of the flowering period, with more than $60 \%$ of the total flowers opened in the first week.

Table 1.

Time and length of flowering and flower lifespan for Corydalis solida and C. cava in 2008 and 2012 - 2013, observed in SE Poland (mean \pm SD)

\begin{tabular}{|c|c|c|c|c|c|c|c|c|c|c|c|}
\hline \multirow[t]{2}{*}{ 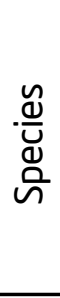 } & \multirow[t]{2}{*}{ Year } & \multicolumn{2}{|c|}{ Flowering } & \multicolumn{2}{|c|}{$\begin{array}{c}\text { Number of } \\
\text { flowers per } \\
\text { inflores- } \\
\text { cence }\end{array}$} & \multicolumn{2}{|c|}{$\begin{array}{c}\text { Number of } \\
\text { inflores- } \\
\text { cences } \\
\text { рег } 1 \mathrm{~m}^{2} \\
\end{array}$} & \multicolumn{2}{|c|}{$\begin{array}{l}\text { Number of } \\
\text { flowers } \\
\text { per } 1 \mathrm{~m}^{2}\end{array}$} & \multicolumn{2}{|c|}{$\begin{array}{l}\text { Lifespan } \\
\text { per single } \\
\text { flower } \\
\text { (d) }\end{array}$} \\
\hline & & Date & $\begin{array}{l}\text { Length } \\
\text { (d) }\end{array}$ & Mean & $\pm S D$ & Mean & $\pm S D$ & Mean & $\pm S D$ & Mean & $\pm S D$ \\
\hline \multirow{4}{*}{ ن? } & 2008 & $29.02-10.04$ & 42 & $11.6_{a}$ & 3.2 & $33.0_{a}$ & 20.3 & $385.0_{a}$ & 295.0 & $14.2_{c}$ & 5.2 \\
\hline & 2012 & $20.03-17.04$ & 29 & $14.7_{b}$ & 5.2 & $70.0_{b}$ & 58.2 & $1050.8_{b}$ & 1148.3 & $11.5_{b}$ & 7.3 \\
\hline & 2013 & $12.04-1.05$ & 19 & $15.9_{b}$ & 4.4 & $73.7_{\mathrm{b}}$ & 43.6 & $1122.7_{b}$ & 688.9 & $6.6_{a}$ & 3.1 \\
\hline & Mean & & 30.0 & $14.1_{B}$ & 4.6 & $58.9_{A}$ & 44.6 & $852.6_{B}$ & 77.8 & $10.8_{A}$ & 8.2 \\
\hline \multirow{4}{*}{ ن } & 2008 & $10.03-15.04$ & 37 & $10.4_{b}$ & 3.4 & $96.5_{c}$ & 31.7 & $941.5_{c}$ & 287.8 & $10.3_{b}$ & 2.4 \\
\hline & 2012 & $26.03-24.04$ & 30 & 7.6 & 2.5 & $57.5_{b}$ & 15.4 & $444.2_{b}$ & 203.0 & $7.1_{\mathrm{ab}}$ & 3.2 \\
\hline & 2013 & $18.04-5.05$ & 18 & $9.4_{b}$ & 2.7 & $26.0_{a}$ & 13.8 & $246.7_{\mathrm{a}}$ & 166.8 & $5.1_{\mathrm{a}}$ & 2.1 \\
\hline & Mean & & 28.3 & $9.1_{A}$ & 3.0 & $60.0_{A}$ & 37.8 & $544.1_{A}$ & 377.4 & $7.4_{A}$ & 2.8 \\
\hline
\end{tabular}

Means in columns with the same letters are not significantly different at $\alpha=0.05$ (Duncan t-test). 

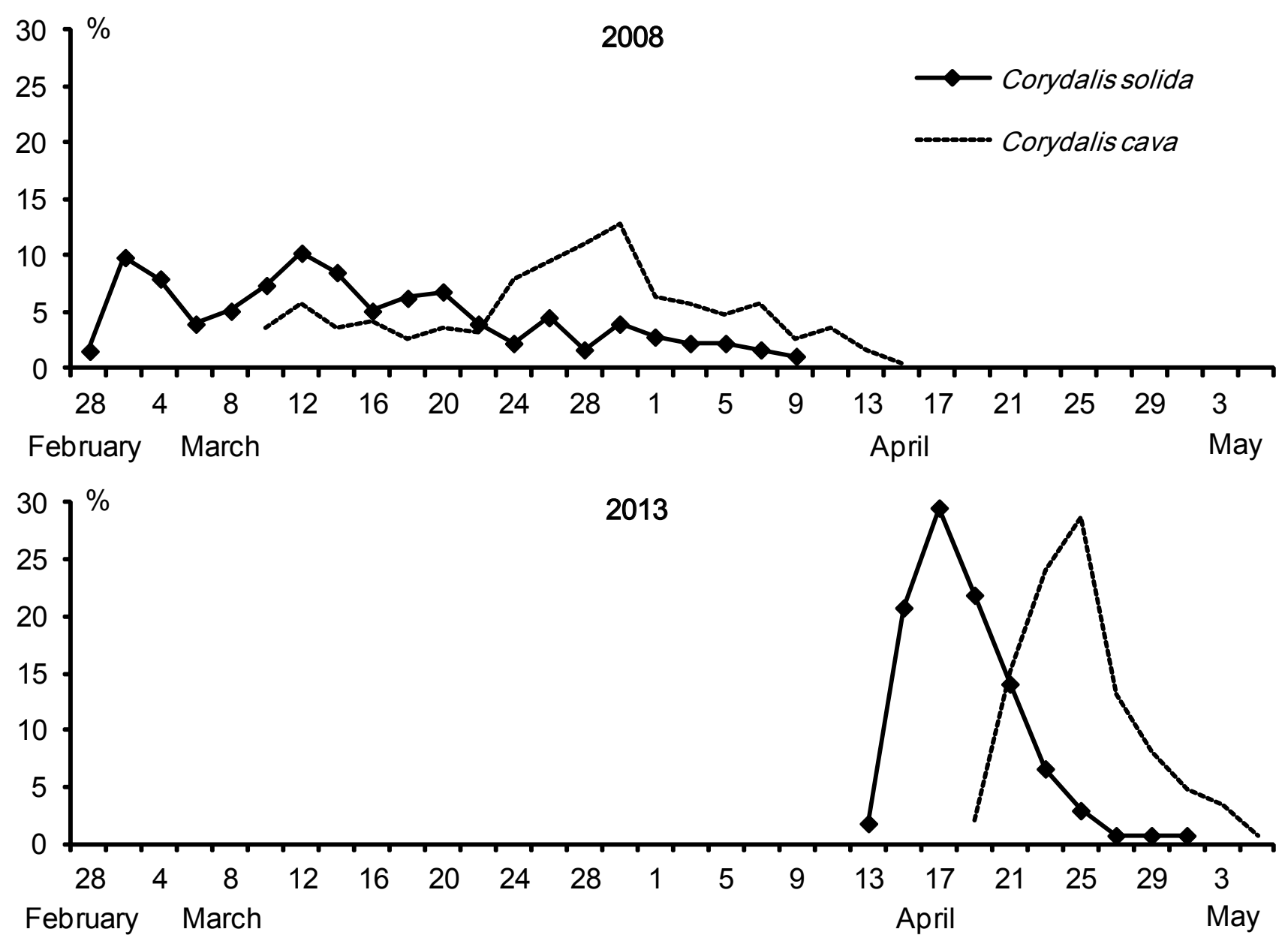

Fig. 1. Seasonal rhythm of blooming of Corydalis solida and C. cava in 2008 and 2013, expressed as a percentage of flowers blooming in consecutive days of flowering in relation to the total number of flowers developed during the flowering season, observed in SE Poland.

Flowers of both Corydalis species aggregate in racemes and commence blooming acropetally, with an early diurnal flower opening pattern (Fig. 2). About 30 - $40 \%$ of the daily openings were observed at $6.00 \mathrm{~h}(\mathrm{GMT}+2 \mathrm{~h})$, followed by a rapid progression, and up to 85 - $90 \%$ of flowers opened before $10.00 \mathrm{~h}$, until termination was recorded at about midday.

The inflorescence size $\left(F_{1,122}=49.61, p=0.004\right)$ and flower density $\left(F_{1,122}=10.84, p=0.001\right)$ differed significantly between the study species (Tab. 1). The single raceme of $C$. solida developed more flowers $($ mean $=14.1 \pm 4.6$, range 8 - 24) than the raceme of $C$. cava (mean $=9.1 \pm 3.0$, range 6 - 16). Significant year-to-year differences were noted in the number of flowers per inflorescence $\left(F_{2,59}=6.59, p=0.002, C\right.$. solida; $F_{2,59}=3.34$, $\mathrm{p}=0.041$, c cava) and in the number of flowers per $1 \mathrm{~m}^{2}\left(F_{2,59}=6.9, p=0.002\right.$, C. solida; $F_{2,59}=60.9$, $p<0.001$, C. cava). The intraspecies disparities in the abundance of blooming between years were
3 - 4 fold. No species effect was found for the duration of the flower lifespan $\left(F_{1,72}=37.61\right.$, $p=0.104$ ), but significant year-to-year differences were noted for the duration of anthesis within both species studied $\left(F_{2,59}=14.21, p=0.021, C\right.$. solida; $F_{2,59}=26.8, p=0.017, C$. cava). In the years 2008 and 2012, the single flower lifespan was 4 - 8 days longer for $C$. solida, and 2 - 3 days longer for $C$. cava as compared to 2013.

In the flowers of both Corydalis species, the nectary glands form the protuberance located above the pedicel, and the bag-like spur serves as a reservoir for nectar (Fig. 3C). The spur is formed from the outer part of two converging petals. The amount of secreted nectar $\left(F_{1,36}=24.05, p<0.001\right)$ and the concentration of sugars $\left(F_{1,36}=86.62, p<0.001\right)$ varied significantly between species. The flowers of C. solida secreted 2-fold higher amounts of nectar (mean $=26.6 \pm 7.5 \mathrm{mg}$ per 10 flowers vs. 12.5 $\pm 8.6 \mathrm{mg}$ for $C$. cava), with a lower sugar concentration $($ mean $=33.0 \pm 14.2$ vs. $54.0 \pm 10.1$ for 


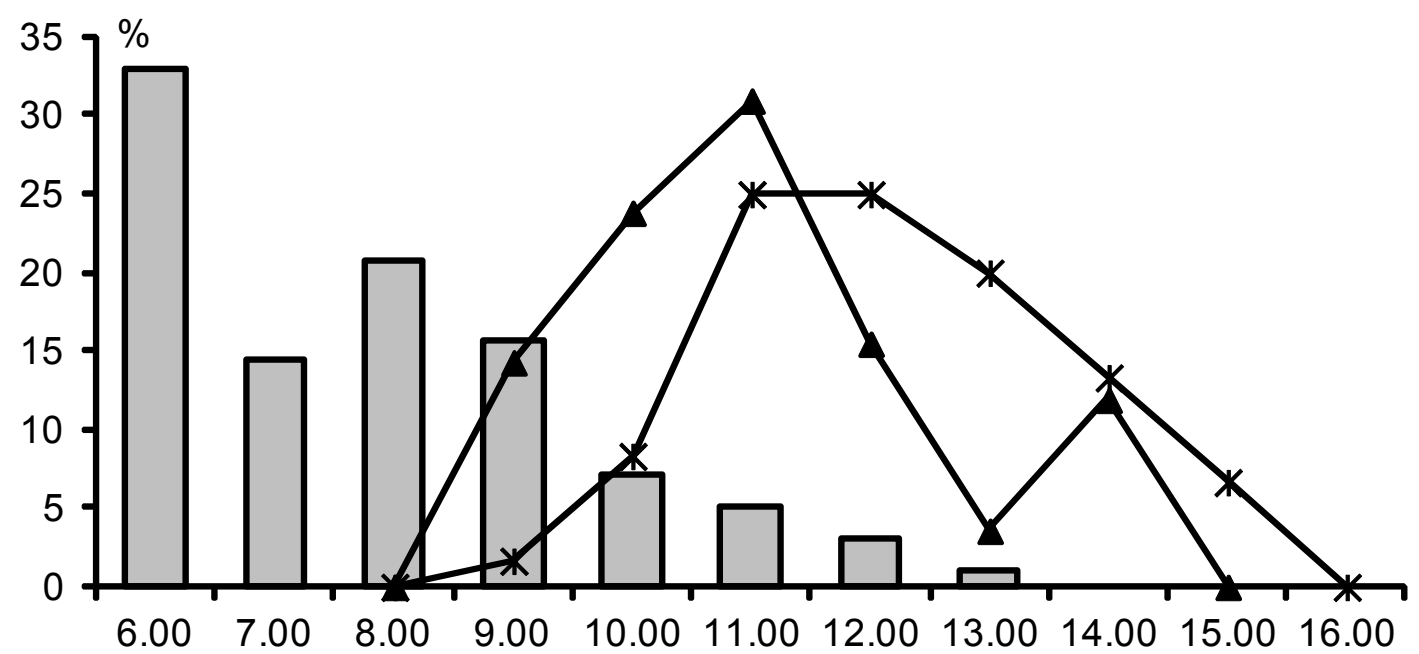

$\square$ flowers $\rightarrow$ Apis mellifera $\longrightarrow$ Bombus spp.

Fig. 2. Diurnal pattern of flowering expressed as the number of flowers opened at 1-h intervals in relation to the total opened during the day, and the diurnal activity of insect visitors observed in SE Poland (means calculated from Corydalis solida and C. cava and from 2008 and 2013).
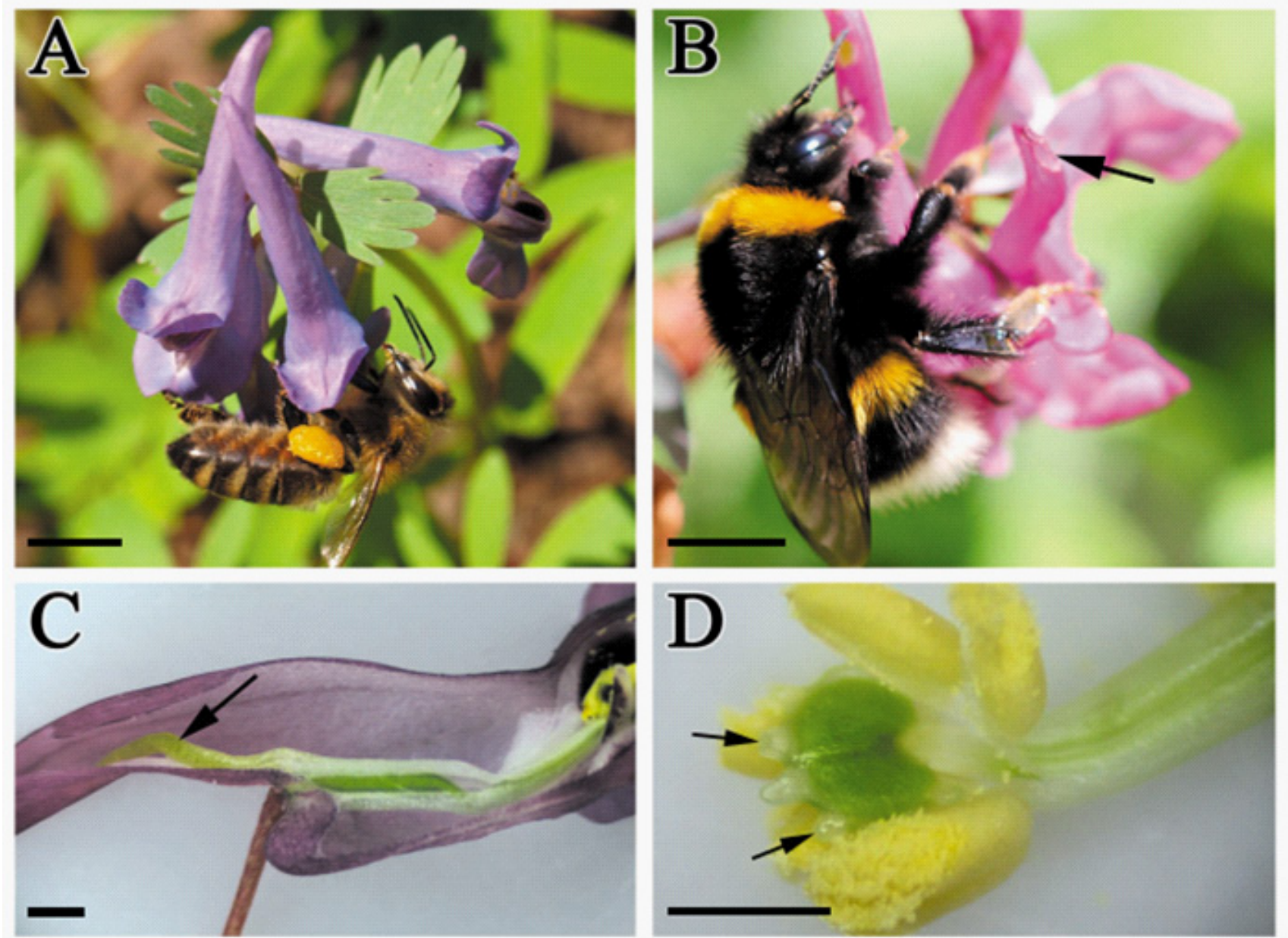

Fig. 3. Macro photographs of Corydalis solida. A. Apis mellifera with pollen loads (scale bar $=5 \mathrm{~mm}$ ). B. Bombus terrestris during nectar robbery; note perforated spur (arrow) (scale bar $=5 \mathrm{~mm}$ ). C. Longitudinal section through the flower with filiform nectary (arrow) located in the spur (scale bar $=1 \mathrm{~mm}$ ). D. Bursting anthers at bud stage; note stigma with wings (arrows) (scale bar $=1 \mathrm{~mm}$ ). 
Table 2.

Concentration of nectar and amount of sugar delivered by Corydalis solida and C. cava in 2008 and 2013, observed in SE Poland (mean \pm SD)

\begin{tabular}{|c|c|c|c|c|c|c|c|c|c|}
\hline \multirow{2}{*}{ 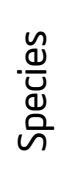 } & \multirow{2}{*}{ Year } & \multirow{2}{*}{$\begin{array}{l}\text { Number of } \\
\text { examined } \\
\text { flowers }\end{array}$} & \multicolumn{3}{|c|}{$\begin{array}{l}\text { Concentration of sugars } \\
\text { in nectar (\%) }\end{array}$} & \multicolumn{3}{|c|}{$\begin{array}{c}\text { Sugars per } \\
10 \text { flowers (mg) }\end{array}$} & \multirow{2}{*}{$\begin{array}{l}\text { Total sugars } \\
\text { yield (kg/ha) }\end{array}$} \\
\hline & & & $\min -\max$ & Mean & $\pm S D$ & $\min -\max$ & Mean & $\pm \mathrm{SD}$ & \\
\hline \multirow{3}{*}{ 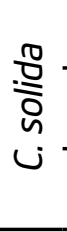 } & 2008 & 102 & 19 - 31 & $27.3_{a}$ & 3.6 & 7.8 - 11.8 & $10.4_{b}$ & 7.1 & 4.0 \\
\hline & 2013 & 123 & $36-47$ & $38.6_{b}$ & 4.6 & $4.2-8.3$ & $5.7_{\mathrm{a}}$ & 1.4 & 6.4 \\
\hline & Mean & & & $33.0_{A}$ & 14.2 & & $8.1_{A}$ & 10.1 & 5.2 \\
\hline \multirow{3}{*}{$\begin{array}{l}\stackrel{0}{0} \\
\stackrel{0}{U}\end{array}$} & 2008 & 114 & $50-60$ & $49.2_{a}$ & 5.2 & $9.0-15.0$ & $8.5_{b}$ & 3.5 & 8.0 \\
\hline & 2013 & 131 & $51-68$ & $58.7_{b}$ & 3.8 & $1.1-8.0$ & 4.7 a & 2.0 & 1.2 \\
\hline & Mean & & & $54.0_{B}$ & 10.1 & & $6.6_{A}$ & 5.6 & 4.6 \\
\hline
\end{tabular}

Means in columns with the same letters are not significantly different at $\alpha=0.05$ (Duncan t-test).

Dry mass of anthers, mass of produced pollen, total pollen yield, and pollen viability

Table 3. in two Corydalis species in 2008 and 2012 - 2013, observed in SE Poland (mean \pm SD)

\begin{tabular}{|c|c|c|c|c|c|c|c|c|c|c|}
\hline \multirow{2}{*}{$\begin{array}{l}\frac{\mathscr{\omega}}{\tilde{\Phi}} \\
\stackrel{\mathscr{n}}{n}\end{array}$} & \multirow{2}{*}{ Year } & \multicolumn{3}{|c|}{$\begin{array}{l}\text { Mass of dry } 100 \text { anthers } \\
\text { with pollen }(\mathrm{mg})\end{array}$} & \multicolumn{3}{|c|}{$\begin{array}{c}\text { Mass of pollen per } 100 \\
\text { anthers (mg) }\end{array}$} & \multirow{2}{*}{$\begin{array}{c}\text { Total } \\
\text { pollen } \\
\text { yield } \\
\text { (kg/ha) }\end{array}$} & \multicolumn{2}{|c|}{$\begin{array}{l}\text { Viability } \\
(\%)\end{array}$} \\
\hline & & $\min -$ & Mean & $\pm S D$ & $\min -\max$ & Mean & $\pm S D$ & & Mean & $\pm S D$ \\
\hline \multirow{4}{*}{ ن } & 2008 & $4.1-5.9$ & $4.9_{\mathrm{a}}$ & 0.8 & $1.6-3.5$ & $2.2_{a}$ & 0.9 & 1.5 & $74.2_{a}$ & 2.2 \\
\hline & 2012 & $6.7-8.6$ & $7.5_{b}$ & 0.9 & $2.7-4.1$ & $3.3_{b}$ & 0.6 & 6.3 & $82.1_{b}$ & 4.1 \\
\hline & 2013 & $3.8-$ & $5.0_{\mathrm{a}}$ & 1.2 & $2.3-3.3$ & $2.9_{a}$ & 0.5 & 4.5 & $89.3_{c}$ & 3.9 \\
\hline & Mean & & $5.8_{A}$ & 1.5 & & $2.8_{B}$ & 0.7 & 4.1 & $81.9_{A}$ & 7.2 \\
\hline \multirow{4}{*}{ 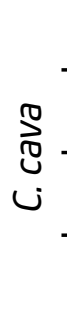 } & 2008 & $2.7-4.7$ & $3.6_{a}$ & 0.9 & $0.8-1.2$ & $1.0_{\mathrm{a}}$ & 0.2 & 2.6 & $87.2_{a}$ & 3.1 \\
\hline & 2012 & $3.5-5.1$ & $4.3_{\mathrm{a}}$ & 0.9 & $1.6-2.2$ & $1.9_{a}$ & 0.3 & 1.5 & $94.4_{b}$ & 1.8 \\
\hline & 2013 & $9.3-13.1$ & $10.8_{b}$ & 1.7 & $1.0-2.1$ & $1.6_{\mathrm{a}}$ & 0.5 & 2.1 & $99.8_{c}$ & 0.2 \\
\hline & Mean & & $6.2_{A}$ & 3.6 & & $1.5_{\mathrm{A}}$ & 0.5 & 2.1 & $93.8_{B}$ & 8.1 \\
\hline
\end{tabular}

Means in columns with the same letters are not significantly different at $\alpha=0.05$ (Duncan t-test).

C. cava) (Tab. 2). No species effect was found for the total sugar mass produced in flowers $\left(F_{1,36}=2.90\right.$, $p=0.097)$. The studied nectar characteristics varied among growing seasons (amount of nectar, $F_{1,36}=28.60, \quad p<0.001$; sugar concentration, $F_{1,36}^{1,36}=9.04, p=0.004$; sugar mass, $F_{1,36}=30.64$, $p<0.001$ ). The mass of produced sugars in 2008 was almost twice that of 2013. The average sugar yield of the two Corydalis species was similar $4.6 \mathrm{~kg} / \mathrm{ha}$
(C. cava) and $5.2 \mathrm{~kg} / \mathrm{ha}$ (C. solida). Considerable differences were noted between years, however, mainly in the case of $C$. cava (1.2 - $8.0 \mathrm{~kg} / \mathrm{ha})$.

In the flowers of the Corydalis species, filaments of the stamens are fused in two sets. Each group consists of one complete (2 anthers) and two incomplete stamens (1 anther), which results in 8 anthers per flower (Fig. 3D). The pollen is released in the bud stage and is shed into the cavity of 
the wing-plates that cover the top of the stigma. Generally, the anthers of both species were similar in size $\left(F_{1,21}=0.28, p=0.602\right)$ but delivered significantly different amounts of pollen $\left(F_{1,21}=23.72\right.$, $p<0.001)$. The anthers of $C$. solida produced twice as much pollen as $C$. cava, on average $2.8 \mathrm{mg}$ and $1.5 \mathrm{mg}$ per 100 anthers, respectively (Tab. 3). This species effect also was found for pollen viability $\left(F_{1,33}=43.12, p=0.032\right)$, with more viable pollen grains observed in $C$. cava. The average estimated pollen productivity per unit area depended on the species and related to the abundance of blooming and changeable mass of pollen produced in anthers. In the full flowering phase, the pollen yield was $2.1 \mathrm{~kg} / \mathrm{ha}$ (C. cava) and $4.1 \mathrm{~kg} / \mathrm{ha}$ (C. solida).

Corydalis solida and $C$. cava received visits from Apis mellifera and female bumblebees (Bombus spp.) (Fig. $3 \mathrm{AB}$ ). In the early morning hours, bumblebees dominated, representing about $80 \%$ of the visits between $9.00-10.00 \mathrm{~h}$; between $11.00-15.00 \mathrm{~h}$, honeybees predominated (Fig. 2). The insect visitors initiated visits at about $8.00-9.00 \mathrm{~h}$ and finished activity at $15-16.00 \mathrm{~h}$, about the same time every day, irrespective of species.

The insect visitor response to the air temperature was observed. When the maximum daily air temperature was under $12^{\circ} \mathrm{C}$, honeybees did not visit the Corydalis flowers at all whereas bumblebees visited the Corydalis flowers very rarely. Apis mellifera predominated on both Corydalis species (mean of total visitors, $68.0 \%$ for $C$. solida and $62.5 \%$ for C. cava)

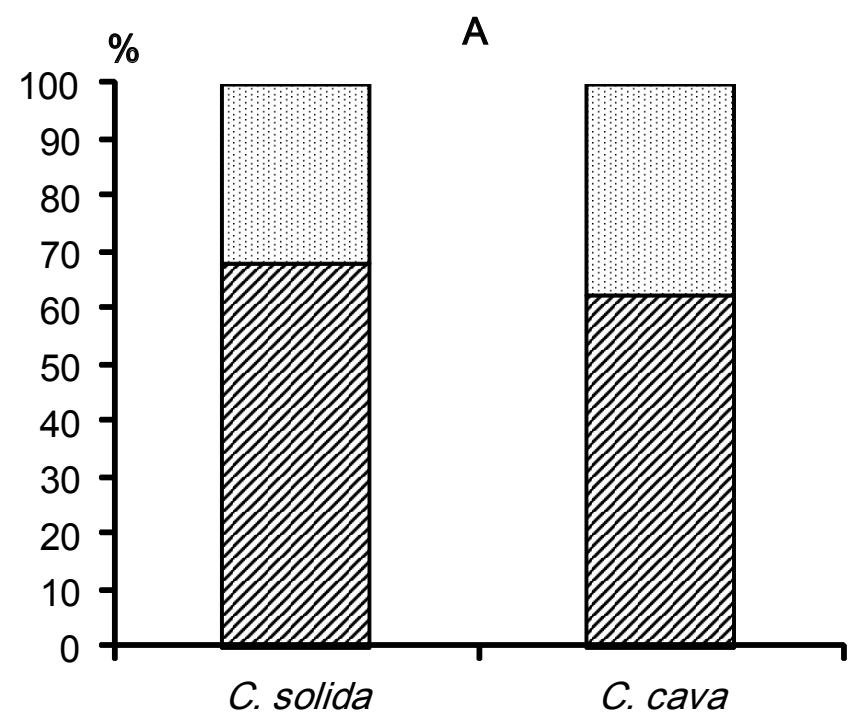

$\square$ Apis mellifera $\square$ Bombus spp. and constituted $65.3 \%$ of visitors, on average (Fig. 4A). The honeybees foraged mainly for pollen while bumblebees collected mainly nectar, irrespective of plant species (Fig. 4B).

\section{DISCUSSION}

The flowering of $C$. solida and $C$. cava took place before the trees of the canopy layer began developing leaves, which is typical for the spring ground layer flora of deciduous forests (Gluchov, 1950; Szklanowska, 1979; Lipiński, 2010). The study period included years with a great contrast between the warm spring of 2008 and cold spring of 2013, in which locally over $27 \mathrm{~cm}$ of snow layer during the month of April was noted. Thus, the disparity between 2008 and 2013 for the onset of blooming for Corydalis spp. was 30 days. The influence of meteorological factors, i.e., air temperature and precipitation level, on the onset, duration, and abundance of flowering has been described for different taxa (Jabłoński and Szklanowska, 1997; Denisow, 2009a, b). In natural communities, the differences for the onset and duration of the blooming period were found for woodland herbs by Szklanowska (1979) and for ruderal species by Denisow (2011), and the disparities were particularly noticeable for the early spring taxa.

The flowering period of the two Corydalis spp. varied significantly, from 18 to 42 days. A similar duration of flowering (17 - 31 days) has been described for

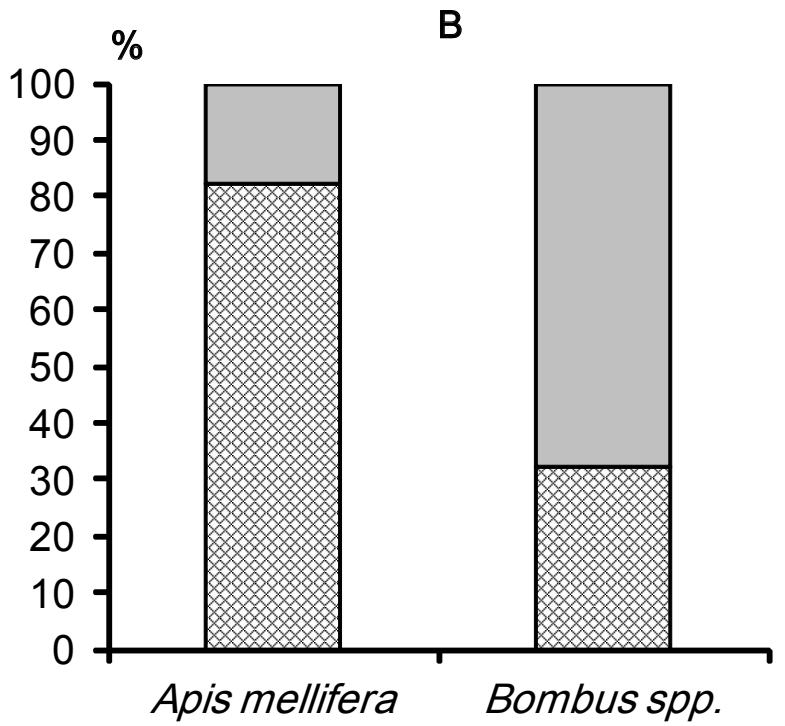

๑pollen foragers $\square$ nectarforagers

Fig. 4. Participation of insect visitors in two Corydalis species observed in SE Poland. A. Means calculated from 2008 and 2012-2013 and proportion of nectar and pollen foragers of Apis mellifera and Bombus spp. B. Means calculated from C. solida and C. cava and from the years of study 
Corydalis ambigua from an Asian temperate zone (Yasaca et al., 1998). Regardless of the species, we also identified differences in the seasonal flowering pattern. A long and slow distributed pattern was observed in the year 2008, with air temperature on average stable during flowering, or slightly below the norm, while the pattern in 2013 shifted to shorter and explosive with considerably delayed flowering in the season. Generally, plants differ greatly with respect to the manner of flower display in the season, depending on flowering time or environmental conditions (Jabłoński and Szklanowska, 1997; Denisow, 2009b). Seasonal development of flowers from continuous to asymmetrical has been observed for different taxa, e.g., Geranium platypetalum (Masierowska, 2012). In natural plant communities, flowering expanded in time is especially characteristic for the species that bloom at the beginning of the growing season (Denisow, 2011) and is considered as a part of both the pollination system and reproductive strategy (Faegri and van der Pijl, 1979). As emphasized by Goulson (1999), the insect populations are small in size during the initial weeks of the growing season, and the character of seasonal Corydalis species blooming seems to be adapted to low insect visitor density. Synchronous blooming of the flowers of the species in a given plant population is very important for the energetics of pollination. Early in the season, temperature drops are frequent; therefore, the pattern of blooming minimizes the energy expenditure of the pollinators flying between plants (Heinrich and Raven, 1972; Kudo and Ida, 2013).

The corolla of the studied Corydalis species persisted on the pedicel even for 14 days, which is consistent with the findings of Olesen (1996) for $C$. solida in Danish forests (approx. 9 - 14, up to 25 days of flower longevity). The flower lifespan depends in part on the air temperature, air humidity, and whether or not the flower is pollinated (Ashman and Shoen, 1994; Denisow, 2009a). Prolonged anthesis is important, especially in the case of the early spring blooming species, and may raise the probability that flowers are visited by pollinators. The flower lifespan may also change depending on the phenology. Yasaka et al. (1998) documented a shorter anthesis of $C$. ambigua flowers blooming in the late season compared to blooming in the earlier season. Accordingly, in our study, shorter anthesis was recorded in 2013, in the late flowering time (April-May), as compared to the early flowering time (March-April) in 2008.
The studied species developed numerous flowers per inflorescence; however, the racemes of $C$. solida developed more flowers, which confirms the descriptions of Rutkowski (2004) and indicates that this feature is highly genetically determined. The density of flowers per $1 \mathrm{~m}^{2}$ varied substantially among growing seasons (247 - 1122). The considerably lower abundance of blooming-only 165 flowers per $\mathrm{m}^{2}$ for C. solida-was noted by Szklanowska (1979). As highlighted by different authors, the habitat (soil type, nutrients) and environmental conditions (temperature, humidity) are essential for the abundance of blooming (Lipiński, 2010; Denisow, 2011). Also, the dynamics of the population, i.e., the participation of generative and vegetative individuals, is changeable during the life history of clonal species, which may considerably affect the abundance of blooming (Goldenberg and Zobel, 1997). Although a detailed population study was not planned, we observed a changeable proportion of generative and vegetative individuals in the patches during the years of study. Additionally, in a woodland community, the progress of herbaceous species is limited by interspecies competition from, for example, shrubs and trees. Numerous juvenile and adult individuals of shrubs and trees were found, overgrowing in the bottom of the loess gorge where the population of C. cava occurred. An increase in the density of canopy closure results in an unsuitable habitat for photosynthesis and limits the portion of the starch stored in the underground vegetative organs and thus carbohydrates allocated to reproductive organs; the consequence can be reduced abundance of flowering. Goldenberg and Zobel (1997) reported poor growth and a decrease in the flowering for Corydalis aquaegelidae, also a forest species, when the canopy level reached over $90 \%$ closure.

The strategies for luring insect visitors to Corydalis flowers involve various features. Because of the early phenology, the Corydalis species are attractive to $A$. mellifera and bumblebee queens. The character of floral reward and the morphological and biological flower traits affect the behavior of insect visitors. We observed nectar-robbing behavior of bumblebees, which is similar to bumblebee foraging behavior on Corydalis described by Higashi et al. (1988). Nectar robbing occurs in over 150 flowering species across 40 botanical families and relates to flower type (floral tubes or nectar spurs) with deeply hidden nectar (Faegri and van der Pijl, 1979). Nectar in the studied Corydalis species was accumulated in the deep spur and was difficult to obtain by shorttongued bees; thus, honeybees frequently avoided 
it. At the same time, the highly protandrous flowers, with pollen release in the bud stage and pollen accessibility in the moment of flower opening, explain the preferences of $A$. mellifera in foraging mainly for pollen.

The total sugar yield ( $4.6-5.2 \mathrm{~kg} / \mathrm{ha}$ ) of the studied Corydalis species was much lower than established for other forest species, e.g., Pulmonaria officinalis L. (30 kg/ha) or Ajuga reptans L. (120 kg/ha) (Szklanowska, 1973; Kołtowski, 2006). However, the plants support insect visitors as one of the earliest energy food supplies during the growing season. According to various authors (e.g., Banaszak, 1992; Corbet, 2000; Delaplane and Mayer, 2000; Denisow, 2011), the conservation of all flower-visiting species within plant communities is required to maintain insect biodiversity. A shortage of food early in the season because of changes in the local flora may pose a serious threat to populations of pollinators, and an early blooming species (e.g., Fritillaria meleagris) might be a major food source for several species of bumblebees (Zych and Stpiczyńska, 2011).

Our study is the first on the pollen yield of Corydalis species. The mass of pollen offered by $C$. solida anthers was 1.2 - 2.0 fold higher than that delivered by C. cava. As reported by Denisow (2009a, 2011), the mass of pollen produced is a highly genetically dependent feature and thus varies greatly among species, even within the same genera. Interestingly, regardless of taxon, we found no significant yearto-year differences in the mass of pollen produced in anthers. This result indicates that microsporogenesis and pollen production in these Corydalis species are resistant to external factors (e.g., temperature drops or precipitation shortage). This inference highlights the importance of $C$. cava and $C$. solida as a protein food for entomofauna, although differences in the total pollen yield between years were substantial (1.3 - $6.4 \mathrm{~kg} / \mathrm{ha}$ ). The fluctuation was mainly the result of the varied density of flowers, but an advantageous feature is annual spontaneous plant renewal, which ensures repeatable flowering.

In conclusion, C. solida and C. cava exhibit high phenotypic plasticity of timing of flowering and develop flowers with floral reward beneficial for Apidae visitors at the beginning of a growing season, a period of high food demand because of development of insect offspring. Increased planting of $C$. solida and $C$. cava as ornamentals in naturalistic parks and gardens may enrich poor early spring flowers, mainly in pollen for honeybees and carbohydrates for bumblebee queens.

\section{ACKNOWLEDGEMENTS}

This research was supported financially by the Ministry of Science and Higher Education of Poland (project OKB/DS/2) as a part of statutory activities of the Department of Botany, University of Life Sciences in Lublin. We would like to thank Sebastian Antoń, MSc, for assistance with photographic documentation.

\section{REFERENCES}

Angiosperm Phylogeny Group (2009) An update of the Angiosperm Phylogeny Group classification for the orders and families of flowering plants: APG III. Botanical Journal of the Linnean Society 161 (2): 105-121.

Ashman T. L., Shoen D. J. (1994) How long should a flower live? Nature 371: 788-790.

Banaszak J. (1983) Ecology of bees (Apoidea) of agricultural landscape. Polish Ecological Studies 9(4): 421-505.

Banaszak J. (1992) Strategy for conservation of wild bees in an agricultural landscape. Agriculture Ecosystems and Environment 40: 179-192.

Bodnarczuk L. I., Solomacha T. D., lliasz A. M., Solomacha W. A. (1993) Atlas medonosnich roslin Ukrainy. Urożaj. Kijev. 269 pp..

Corbet S. A. (2000) Conserving compartments in pollination webs. Conservation Biology 14: 129-131.

Delaplane K. S., Mayer D. F. (2000) Crop pollination by bees. CABI Publishing. New York. 344 pp.

Denisow B. (2009a) Pollen production, flowering and insect visits on Euphorbia cyparissias L. and Euphorbia virgultosa Klok. Journal of Apicultural Science 48(1): 50-59.

Denisow B. (2009b) Factors determining diurnal dynamics of blooming of chosen plants species. Acta Agrobotanica 62(1): 83-89.

Denisow B. (2011) Pollen production of selected ruderal plant species in the Lublin area. University of Life Sciences Press. Lublin. 86 pp.

Faegri K., van der Pijl L. (1979) The principles of pollination ecology. 3rd rev. ed. Pergamon Press. Oxford. 244 pp. 
Fahn A. B. (1988) Secretory tissues in vascular plants. New Phytologist 108: 229-257.

Gluchov M. (1950) Vażniejszyje miedonosnyje rastienija i sposoby ich razviedienija. Gosudar. Izdat. Selskochoz. Lit., Moskva. 512 pp.

Goldenberg D. M., Zobel D. B. (1997) Allocation, growth and estimated population structure of Corydalis aquaegelidae, a rare riparian plant. Northwest Science 71: 196204.

Goulson D. (1999) Foraging strategies of insects for gathering nectar and pollen, and implications for plant ecology and evolution. Perspectives in Plant Ecology, Evolution and Systematics 2(2): 185-209.

Heinrich B., Raven P. H. (1972) Energetics and pollination ecology. Science 176: 597-602.

Heywood V. H. (1985) Flowering plants of the world Croom Helm. London and Sydney. 336 pp.

Higashi S. M., Ohara H., Arai H., Matsuo K. (1 988) Robberlike pollinators: overwintered queen bumble bees foraging on Corydalis ambigua. Ecological Entomology 13: $411-418$

Jabłoński B. (2002) Notes on the method to investigate nectar secretion rate in flowers. Journal of Apicultural Science 46(2): 117-125.

Jabłoński B., Szklanowska K. (1997) Wpływ niektórych czynników pogody na kwitnienie, nektarowanie, pylenie i oblot przez owady entomofilnych roślin uprawnych. In: Biologia kwitnienia, nektarowania i zapylania roślin. 1 Ogólnopolska Konferencja Naukowa. Lublin - Poland. 1314 listopada 1997: 53-58.

Kołtowski Z. (2006) Wielki Atlas Roślin Miododajnych. Wydanie Rzeczpospolita. Warszawa. 327 pp.

Kudo G., Ida T. Y. (2013) Early onset of spring increases the phenological mismatch between plants and pollinators. Ecology 94: 231 1-2320. DOl:10.1890/12-2003.1

Lipiński M. (2010) Pożytki pszczele. Zapylanie i miododajność roślin. IV ed. PWRiL Warszawa. 320 pp.

Masierowska M. (2012) Floral phenology, floral rewards and insect visitation in an ornamental species Geranium platypetalum Fisch. \& C. A. Mey., Geraniaceae. Acta Agrobotanica 65(2): 23-36.
Matuszkiewicz W. (2012) Przewodnik do oznaczania zbiorowisk roślinnych Polski. PWN. Warszawa. 536 pp.

Olesen J. M. (1996) From naïveté to experience: Bumblebee queens (Bombus terrestris) foraging on Corydalis cava (Fumariaceae). Journal of the Kansas Entomological Society 69(4): 274-286.

Rutkowski L. (2004) Klucz do oznaczania roślin naczyniowych Polski niżowej. Wydawnictwo Nauk PWN. Warszawa. 814 pp.

Stanisz A. (1996) Przystępny kurs statystyki z zastosowaniem Statistica na przykładach z medycyny. Statsoft Polska. Kraków. 359 pp.

Stawiarz E., Wróblewska A. (2010) Melisopalinological analysis of multifloral honeys from the Sandomierska Upland area of Poland. Journal of Apicultural Science 54(1): 65-75.

Szklanowska K. (1973) Bory jako baza pożytkowa pszczół. Pszczelnicze Zeszyty Naukowe 17: 51-85.

Szklanowska K. (1979) Nektarowanie i wydajność miodowa ważniejszych roślin runa liściastego. Pszczelnicze Zeszyty Naukowe 23: 123-130.

Teper D. (2006) Food plants of Bombus terrestris L. as detarmined by pollen analysis of faeces. Journal of Apicultural Science 50(2): 101-108.

Wasiak A. (2013) Raport o stanie lasów w Polsce. Dyrekcja Generalna Lasów Państwowych. Centrum Informacyjne Lasów Państwowych. Warszawa. 85 pp. Available at: http://bip.lasy.gov.pl/pl/bip/px_ raport_o_stanie_lasow_2011.pdf?page_opener=http\%3A\%2F\%2Fbip. lasy.gov.pl\%2Fpl\%2Fbip\%2Fraporty_i_p

Yasaka M., Nishiwaki Y., Konno Y. (1998) Plasticity of flowers longevity in Corydalis ambigua. Ecological Research 13:211-216.

Zhang Y. W., Yu Q., Zhao J. M., Guo Y. H. (2009) Differential effects of nectar robbing by the same bumble-bee species on three sympatric Corydalis species with varied mating systems. Annals of Botany 104: 33-39.

Zych M., Stpiczyńska M. (2012) Neither protogynous nor obligatory out-crossed: pollination biology and breeding system of the European Red List Fritillaria meleagris L. (Liliaceae). Plant Biology (Stuttgard) 14: 285-294. 